\title{
Effect of a spacer moiety on radiometal labelled Neurotensin derivatives
}

\author{
By A. Mascarin, I. E. Valverde and T. L. Mindt* \\ University of Basel Hospital, Department of Radiology and Nuclear Medicine, Division of Radiopharmaceutical Chemistry, Petersgraben 4, \\ 4031 Basel, Switzerland
}

(Received December 13, 2012; accepted in revised form May 6, 2013)

(Published online October 14, 2013)

\section{Neurotensin / NT(8-13) / Radiotracer / Lu-177 / DOTA / Spacer moiety}

Summary. The binding sequence of the regulatory peptide Neurotensin, NT(8-13), represents a promising tumourspecific vector for the development of radiopeptides useful in nuclear oncology for the diagnosis (imaging) and therapy of cancer. A number of radiometal-labelled NT(8-13) derivatives have been reported, however, the effect of the spacer which connects the vector with the radiometal complex has yet not been investigated systematically. Because a spacer moiety can influence potentially important biological characteristics of radiopeptides, we synthesized three $\left[\mathrm{DOTA}\left({ }^{177} \mathrm{Lu}\right)\right]-\mathrm{X}-\mathrm{NT}(8-$ 13) derivatives and evaluated the effect of a spacer (X) on the physico-chemical properties of the conjugate including lipophilicity, stability, and in vitro receptor affinity and cell internalization.

\section{Introduction}

Regulatory peptides with high affinity towards cell membrane receptors which are over-expressed by cancerous tissues are promising vectors for the development of tumourspecific radiotracers for the molecular imaging of cancer and peptide receptor radionuclide therapy (PRRT) [1,2]. Among other peptides investigated, Neurotensin (NT), or its binding sequence NT(8-13) respectively, has been the subject of radiotracer development for application in nuclear oncology [3-6]. NT is a regulatory peptide present as a hormone in the gastrointestinal tract [7] and as a neurotransmitter in the central nervous system $[8,9]$. The NT receptor (NTR) family consists of the three subtypes, NTR1-3 [10], of which NTR1 is of particular interest for radiotracer development because of its over- expression in various tumours including colon [11], lung [12], prostate [13], and breast cancer [14].

We are interested in the development of novel NT(8-13)based radiotracers with improved biological characteristics (e.g., tumour uptake, in vivo stability, and fast clearance from non-targeted tissue). At the onset of our work, we were surprised to learn that no systematic evaluation of the effect of a spacer unit, which separates the tumour targeting

\footnotetext{
*Author for correspondence (E-mail: Thomas.Mindt@usb.ch).
}

vector $(\mathrm{NT}(8-13))$ from the radioactive reporter probe (e.g. a radiometal complex), has been reported. Because a spacer unit can impact both the in vitro and in vivo properties of such radioconjugates [15], we set out to investigate the effect of a spacer on NT(8-13)-derivatives functionalized $\mathrm{N}$ terminally with the universal macrocyclic chelator $1,4,7,10$ tetraazacyclododecane-1,4,7,10-tetraacetic acid (DOTA) for the labeling with Lu-177. We chose two uncharged spacers of different lipophilicity (aminohexanoic acid (Ahx) and the tetraethyleneglycol ( $\left.\mathrm{PEG}_{4}\right)$ motif), both of which have been successfully used as a spacer moiety in radiometal peptide conjugates $[16,17]$. To assess the necessity of a spacer, a derivative in which the DOTA and NT(8-13) units were directly coupled was also included in the study. The three radioconjugates were evaluated in vitro for a direct side-byside comparison of their physico-chemical properties.

\section{Results and discussion}

Three DOTA-X-NT(8-13) derivatives $\left(\mathrm{X}=\right.$ spacer $=\mathrm{PEG}_{4}$, Ahx, or no spacer) were synthesized by solid phase peptide synthesis using standard Fmoc chemistry (Fig. 1). After cleavage from the solid phase and deprotection, the peptide conjugates were obtained in high purity and acceptable yields after purification by preparative RP-HPLC (Table 1). Identity of compounds $\mathbf{1 - 3}$ was confirmed by electrospray mass spectroscopy.

NT-analogues 1-3 were radiolabelled with $\left[{ }^{177} \mathrm{Lu}\right]-\mathrm{LuCl}_{3}$ in $0.4 \mathrm{M} \mathrm{NH} \mathrm{NH}_{4} \mathrm{OAc}$ buffer at $100{ }^{\circ} \mathrm{C}$ for $30 \mathrm{~min}$ according to literature procedures [18]. Analysis of the radioconjugates $\left[{ }^{177} \mathrm{Lu}(\mathrm{L})\right](\mathrm{L}=\mathbf{1}-\mathbf{3})$ by $\gamma$-HPLC indicated an excellent radiochemical purity and yield of $>98 \%$. Achieved specific activity of the radiopeptides ranged from 2.3-10.8 MBq/nmol.

With radiopeptides $\left[{ }^{177} \mathrm{Lu}(\mathrm{L})\right](\mathrm{L}=\mathbf{1}-\mathbf{3})$ in hands, we next investigated the effect of a spacer moiety on their physico-chemical and in vitro properties. First, we examined the cell internalization behaviour of the novel compounds in vitro with NTR1-expressing HT-29 cells (Fig. 2 and Table 2). Specificity of NTR1-mediated uptake was verified in each case by blocking experiments in the presence of 1000-fold excess NT(8-13). $\left[{ }^{177} \mathrm{Lu}(\mathrm{L})\right](\mathrm{L}=\mathbf{1 - 3})$ 
<smiles>CCC(C)C(NC(=O)C(Cc1ccc(O)cc1)NC(=O)C1CCCN1C(=O)[C@H](CCCNC(=N)N)NC(=O)[C@H](CCCNC(=N)N)NC(=O)CCOCCOCCOCCOCCNC(=O)CN(CCN(CCN(CC(=O)O)CC(=O)O)CC(=O)O)CCN(CC(=O)O)CC(=O)O)C(=O)N[C@@H](CC(C)C)C(=O)O</smiles>

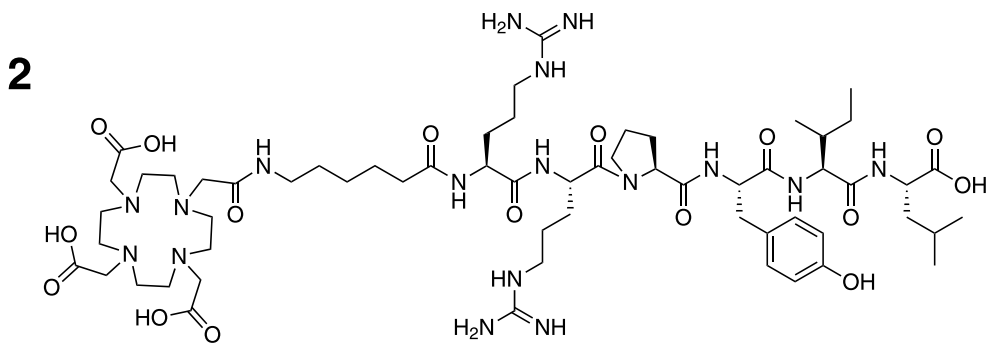<smiles>CCC(C)C(NC(=O)C(NC(=O)C1CCN1C(=O)[C@H](CCCNC(=N)N)NC(=O)C(CCCCNC(=N)N)NC(=O)CN(CCN(CCN(CC(=O)O)CC(=O)O)CC(=O)O)CCN(CC(=O)O)CC(=O)O)C(=O)N[C@@H](Cc1ccc(O)cc1)C(=O)O)C(=O)O</smiles>

Fig. 1. Structures of investigated NT(813) derivatives: DOTA-PEG ${ }_{4}-\mathrm{NT}(8-$ 13) (1), DOTA-Ahx-NT(8-13) (2) and DOTA-NT(8-13) (3).

Table 1. Analytical data of NT derivatives (1-3).

\begin{tabular}{lcccc}
\hline Compound & Yield $^{a}$ & Purity & Calc. mass & Mass observed \\
\hline $\mathbf{1}$ & $21 \%$ & $>98 \%$ & 1449.82 & {$[\mathrm{M}+\mathrm{H}]^{+}=1450.9$} \\
$\mathbf{2}$ & $32 \%$ & $>98 \%$ & 1315.76 & {$[\mathrm{M}+\mathrm{H}]^{+}=1316.9$} \\
$\mathbf{3}$ & $19 \%$ & $>98 \%$ & 1202.68 & {$[\mathrm{M}+\mathrm{H}]^{+}=1203.7$} \\
\hline
\end{tabular}

a: Yield after RP-HPLC purification.

showed specific cell internalization rates of approx. 3-7\% after $4 \mathrm{~h}$ of incubation, a rate comparable to data reported for related radiometal labelled NT(8-13) derivatives [19]. Of the compounds tested, those with a spacer moiety exhibited a significant higher internalization rate than derivative $\left[{ }^{177} \mathrm{Lu}(3)\right]$ without a spacer. Next, we performed receptor binding saturation assays in order determine the affinity $\left(K_{\mathrm{D}}\right)$ of $\left[{ }^{177} \mathrm{Lu}(\mathrm{L})\right](\mathrm{L}=\mathbf{1}-\mathbf{3})$ towards the NTR1 receptor (Fig. 2 and Table 2). Again, receptor specificity was verified by blocking experiments. All derivatives $\left[{ }^{177} \mathrm{Lu}(\mathrm{L})\right](\mathrm{L}=$ 1-3) showed a high and specific affinity towards the NTR1 receptor with $K_{\mathrm{D}}$ values in the single-to-two-digit nanomolar range, a value typically observed for NT-based radiotracers [5]. In general, derivatives with a spacer $\left(\left[{ }^{177} \mathrm{Lu}(\mathrm{L})\right](\mathrm{L}=\right.$ 1,2)) exhibited a more favourable $K_{\mathrm{D}}$ than $\left[{ }^{177} \mathrm{Lu}(\mathbf{3})\right]$ which lacks such a moiety. Thus, the data obtained from the in vitro evaluation of the compounds suggests that the presence of a spacer moiety in radiometal-based NT(8-13) conjugates can be advantageous.
It is known that the spacer unit of a radiometal-labelled peptide can alter the lipophilicity of the conjugate, which in turn can impact its pharmacokinetic and -dynamic profile (e.g., rate and route of excretion) $[4,20]$. We therefore determined the partition coefficient $(\log \mathrm{D})$ of $\left[{ }^{177} \mathrm{Lu}(\mathrm{L})\right]$ $(\mathrm{L}=1-3)$ in $n$-octanol/PBS by the shake flask method for a qualitative comparison of the compounds' lipophilicities ( $n=3$ in quintuples; Table 2). To our surprise, neither the presence of a spacer nor its chemical composition appeared to influence significantly the $\log D$ of the conjugates. It is therefore likely that either the amino acid sequence of NT(8-13) and/or the ${ }^{177}$ Lu-DOTA chelate determine the lipophilic character of the conjugates. Regardless, compound $\left[{ }^{177} \mathrm{Lu}(\mathbf{1})\right]$ with a $\mathrm{PEG}_{4}$ spacer exhibited the highest hydrophilicity, a characteristic which could be considered as an indicator for a potential favourable fast renal excretion of the radiotracer in vivo $[17,20]$.

Another important property of radiolabelled regulatory peptides is their instability towards intra- and extracellular proteases. Rapid degradation in vivo often results in a biological half-life of only a few minutes [21]. It has been shown that an increased stability of radiolabelled peptides correlates with an enhanced accumulation of radioactivity in targeted tissue, an important parameter for both diagnostic and therapeutic applications [22]. Even though the focus of the work presented herein does not lie on the stabilization of the peptidic vector, we investigated the effect of a spacer on the stability of the NT(8-13) derivatives (Table 2). Thus, $\left[{ }^{177} \mathrm{Lu}(\mathrm{L})\right](\mathrm{L}=\mathbf{1 - 3})$ were incubated in blood serum for 

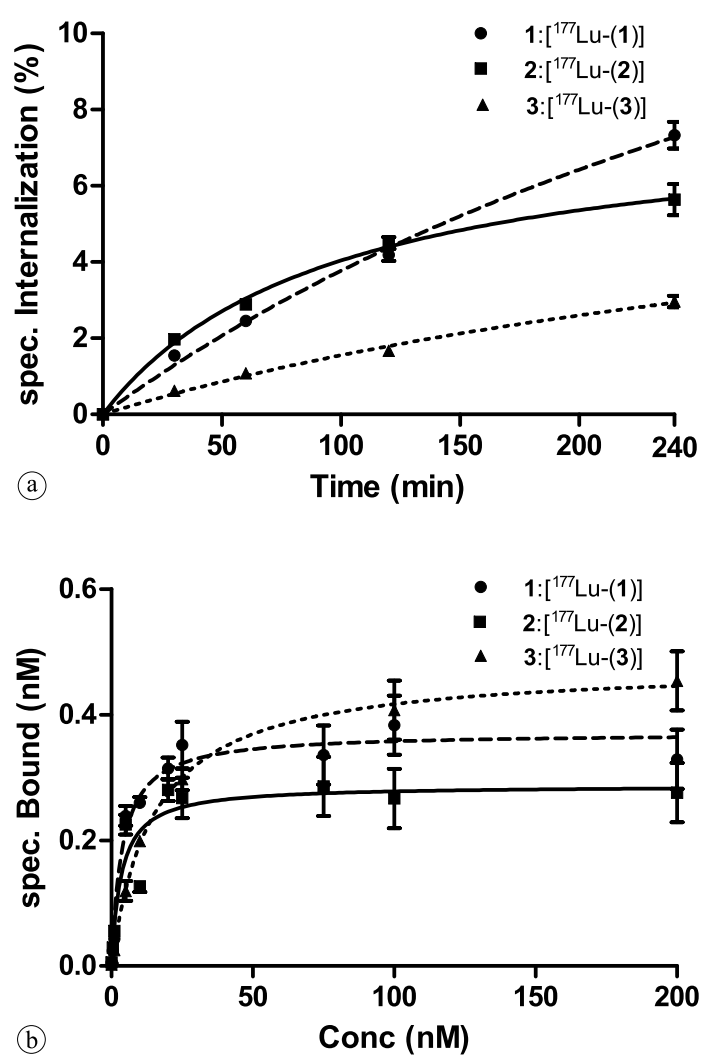

Fig. 2. In vitro evaluation of $\left[{ }^{177} \mathrm{Lu}(\mathrm{L})\right](\mathrm{L}=\mathbf{1}-\mathbf{3})$ with NTR1 expressing HT-29 cell. (a) Specific cell internalization and (b) receptor binding saturation experiments. Data is presented as mean \pm standard deviation ( $n=3$ in triplicates) and fitted by non-linear regression with GraphPad Prism 5.0.

Table 2. Summary of the physico-chemical properties of $\left[{ }^{177} \mathrm{Lu}(\mathrm{L})\right](\mathrm{L}$ $=\mathbf{1}-\mathbf{3})$.

\begin{tabular}{|c|c|c|c|c|}
\hline Compound & $\%$ internalization ${ }^{a}$ & $K_{\mathrm{D}}[\mathrm{nM}]$ & $\log P$ & $T_{1 / 2}^{b}$ \\
\hline$\left[{ }^{177} \mathrm{Lu}(\mathbf{1})\right]$ & $7.3 \pm 0.4$ & $3.8 \pm 0.9$ & -2.6 & $<5 \min$ \\
\hline$\left[{ }^{177} \mathrm{Lu}(\mathbf{2})\right]$ & $5.6 \pm 0.4$ & $3.4 \pm 1.5$ & -2.3 & $<5 \min$ \\
\hline$\left[{ }^{177} \mathrm{Lu}(\mathbf{3})\right]$ & $3.0 \pm 0.2$ & $14.9 \pm 0.7$ & -2.5 & $<5 \mathrm{~min}$ \\
\hline
\end{tabular}

a: Specific cell internalization after $4 \mathrm{~h}$ of incubation;

b: Half-life $\left(T_{1 / 2}\right)$ in blood serum.

up to $2 \mathrm{~h}$ at $37^{\circ} \mathrm{C}$ and samples were taken at different time points. After precipitation of proteins, the supernatant was analyzed by $\gamma$-HPLC for determination of the ratio of intact radiopeptide versus proteolytic degradation products. Not surprisingly, all compounds exhibited a short half-life $\left(T_{1 / 2}\right)$ of approx. $<5 \mathrm{~min}$. Similar half-lifes have been reported for non-stabilized derivatives of the native binding sequence of Neurotensin [5]. The experimental data indicate, that a spacer unit does not seem to have a significant effect on the stability of the NT(8-13) conjugates in blood serum.

\section{Conclusions}

In summary, we report the synthesis, radiolabelling and in vitro evaluation of three ${ }^{177} \mathrm{Lu}$-labelled DOTA-NT(8-13) derivatives in order to assess the effect of a spacer moiety on their physico-chemical properties. We were able to show that a spacer moiety between the targeting peptide NT(8-13) and the radiometal chelate $\left[{ }^{177} \mathrm{Lu}(\mathrm{DOTA})\right]$ is beneficial with regards to receptor affinity and cell internalization properties of the conjugate in vitro. On the other hand, the presence of a spacer and/or its chemical composition had little influence on the lipophilicity and blood serum stability of the radiopeptide. For our on-going work on the development of novel NT-based radiotracers, we will account for these data and include a spacer as a structural element of the conjugate.

\section{Experimental procedures}

\subsection{General procedures}

HOBt, HATU AND TBTU were purchased from Merck Biosciences (Nottingham, UK). The preloaded resin FmocL-Leu-PEG-PS was purchased from Applied Biosystems (Warrington, UK). Fmoc- $\mathrm{PEG}_{4}-\mathrm{OH}$ was purchased from PolyPeptide Group (Strasbourg, France). Fmoc-amino acids and Neurotensin (8-13) was purchased from Bachem (Bubendorf, Switzerland). DOTA $(t \mathrm{Bu})_{3}$,was purchased from Chematech (Dijon, France). Solvents and other chemicals were purchased from Acros Organics (Geel, Belgium), Merck (Darmstadt, Germany) or Sigma-Aldrich (Buchs, Switzerland). Automated solid-phase synthesis was performed on a Pioneer synthesizer (Applied Biosystems). Polypropylene syringes for manual peptide couplings, fitted with polypropylene frits and plungers were obtained with MultiSynthech (Witten, Germany). ${ }^{177} \mathrm{LuCl}_{3}$ in $0.05 \mathrm{M} \mathrm{HCl}$ was purchased either from IDB (Baarle-Nassau, Netherlands), ITG (München, Germany) or Perkin Elmer (Boston, USA). Analytical and preparative HPLC were carried out with systems from Bischoff Chromatography, equipped with a $\lambda-1010 \mathrm{UV} / \mathrm{Vis}$ and an LB509 radioflow detector (Berthold Technologies), using C18 reversed-phase columns (Macherey Nagel Nucleodur C18 ISIS, 5 mm (Column A), 250 x $4.6 \mathrm{~mm}$ for analytics and Macherey Nagel Nucleodur C18 ISIS, $5 \mu \mathrm{m}, 250 \times 16.0 \mathrm{~mm}$ (Column B) for purifications). HPLC solvents were $0.1 \%$ TFA in $\mathrm{H}_{2} \mathrm{O}(\mathrm{A})$ and $\mathrm{MeCN}$ (B); flow: $1.5 \mathrm{~mL} / \mathrm{min}$. For analytics a linear gradient from $85 \%$ to $50 \%$ A in 20 min was used. Quality control of the radiometal labelled peptides was performed using Column A and a linear gradient using $90 \%$ to $50 \% \mathrm{~A}$ in $15 \mathrm{~min}$; flow: $1.5 \mathrm{~mL} / \mathrm{min}$. Removal of $\mathrm{MeCN}$ from preparative HPLC fractions was performed with a Jouan RC1022 centrifugal evaporator equipped with a Jouan RC90 cooling trap. Lyophilization of the peptides was performed on an Alpha 1-2 LD plus lyophilizer (Christ). LRMS analyses were performed on a ESI Bruker Esquire 3000 plus. Quantitative $\gamma$-counting was performed on a COBRA II auto-gamma system (Model 5003, Packard Instruments).

\subsection{Solid phase synthesis}

The amino acid sequence of Neurotensin (8-13) was synthesized on solid support (Fmoc-L-Leu-PEG-PS resin; $0.03 \mathrm{mmol}$ ) using standard Fmoc chemistry on an automated peptide synthesizer. TBTU-HOBt was used as a coupling reagent and $20 \%$ piperidine in $\mathrm{DMF}$ as the deprotection reagent. Automated syntheses were carried out with a 4-fold excess of protected amino acids and coupling reagents. For the manual solid phase syntheses, 3-fold excess of protected 
coupling moiety (spacer and chelator, respectively) in presence of HATU (3.0 eq) and DIPEA (5.0 eq) were used. The couplings were performed in DMF with a standard reaction time of $2 \mathrm{~h}$. Completion of the reaction was confirmed by Kaiser test. Elongation yields were obtained by measuring the UV-absorption of the fluorenylmethylpiperidine adduct after Fmoc-deprotection in 20\% piperidine in DMF $(3 \times 2 \mathrm{~min})$. The peptides were deprotected and cleaved from the resin at $\mathrm{rt}$ for $4 \mathrm{~h}$ using a solution of $95 \%$ TFA, $2.5 \% \mathrm{H}_{2} \mathrm{O}$ and $2.5 \%$ trisisopropylsilane as a cleavage cocktail. After removal of the TFA by evaporation and precipitation in cold diethyl ether, the crude peptide obtained was washed three times with cold diethyl ether and purified by preparative RPHPLC. After purification, the peptides were lyophilized and characterized by ESI-MS and analytical RP-HPLC.

\subsection{Radiolabelling of the peptides}

For the labelling of the peptides $1-\mathbf{3}$ with ${ }^{177} \mathrm{Lu}$, stock solutions of $1 \mathrm{mg} / \mathrm{mL}$ of the peptides conjugates $\mathbf{1}-\mathbf{3}$ in water were prepared. For each labelling, 10-20 $\mu \mathrm{g}(10-20 \mu \mathrm{L}$ stock solution) were added to $150-300 \mu \mathrm{L}$ of $0.4 \mathrm{M}$ ammonium acetate ( $\mathrm{pH}$ 5.4). 37-122 MBq of a stock solution of ${ }^{177} \mathrm{LuCl}_{3}$ in $\mathrm{H}_{2} \mathrm{O}$ was added and the mixture was incubated for $30 \mathrm{~min}$ at $100^{\circ} \mathrm{C}$. Afterwards, the radiolabelled peptides were incubated with approx. $3 \times 10^{-4} \mathrm{M}$ cold $\mathrm{LuCl}_{3}(0.8$ eq. $)$ for $30 \mathrm{~min}$ at $100{ }^{\circ} \mathrm{C}$. Quality control was performed by $\gamma$ HPLC analysis of a $2 \mu \mathrm{L}$ aliquot of the solution in $30 \mu \mathrm{L}$ of $0.1 \mathrm{M} \mathrm{Ca}$-EDTA. For the experiments described in the following, the labelling solutions were further diluted with a $0.9 \% \mathrm{NaCl}$ to a concentration of $10^{-6} \mathrm{M}$. This solution was used a stock solution for the binding saturation experiments. For internalization experiments, a second dilution to a concentration of $2.5 \times 10^{-8} \mathrm{M}(2.5 \mathrm{pmol} / 100 \mu \mathrm{L})$ was performed.

\subsection{Stability studies}

The radiolabelled peptides $\left[{ }^{177} \mathrm{Lu}(\mathbf{L})\right](\mathrm{L}=\mathbf{1}-\mathbf{3})(30 \mathrm{pmol}$, $1 \mathrm{nM}$ in PBS, pH 5.4) were incubated at $37^{\circ} \mathrm{C}$ with $1 \mathrm{~mL}$ fresh blood serum. At different time points $(0,5,10,15,20$, $30,40,50,60,120,240 \mathrm{~min}$ ) aliquots were taken, proteins were precipitated by addition of $200 \mu \mathrm{L} \mathrm{EtOH}$, centrifugation for $10 \mathrm{~min}$ at $5000 \mathrm{rpm}$ and the supernatant was analysed by $\gamma$-HPLC $(n=3)$.

\section{5 $\log D$ determination}

The lipophilicity of $\left[{ }^{177} \mathrm{Lu}(\mathrm{L})\right](\mathrm{L}=\mathbf{1}-\mathbf{3})$ was determined by the 'shake flask method' measuring the partition coefficient of the radiolabelled peptides in $n$-octanol/PBS. The radiolabelled peptides ( $30 \mathrm{pmol}, 1 \mathrm{nM}$ in PBS; $300-325 \mathrm{kBq}$ ) were added to $1 \mathrm{~mL}$ of a mixture of $n$-octanol/PBS (50\% $\mathrm{v} / \mathrm{v}$ ). The mixture was then mixed thoroughly for $1 \mathrm{~min}$ by vortex. Both layers were separated by centrifugation $(5 \mathrm{~min}$; $1500 \mathrm{rpm})$ and analysed with a gamma-counter $(n=5)$.

\subsection{In vitro experiments}

\section{Cell culturing}

Human colorectal adenocarcinoma (HT-29) cells were obtained from American Type Culture Collection (ATCC,
Manassas, USA) and cultured at $37{ }^{\circ} \mathrm{C}$ and $5 \% \mathrm{CO}_{2}$ in Dulbecco's modified Eagle's medium (DMEM, high glucose) containing $10 \%(\mathrm{v} / \mathrm{v})$ fetal bovine serum (FBS Superior, OXOID, Pratteln, Switzerland), L-glutamine (200 mM), 100 $\mathrm{IU} \mathrm{mL}{ }^{-1}$ penicillin and $100 \mu \mathrm{g} \mathrm{mL}^{-1}$ streptomycin. All the culture reagents, except FBS, were purchased at Bioconcept (Allschwil, Switzerland). The cells were subcultured weekly after detaching them with a commercial solution of trypsin-EDTA $(1: 250)$ in PBS.

\section{Internalization studies}

On the day prior to the experiment, HT-29 cells $\left(10^{6}\right.$ cells per well) were placed in six-well plates with cell culture medium (1\% FBS) and incubated overnight at $37{ }^{\circ} \mathrm{C}$ and 5\% $\mathrm{CO}_{2}$ for allowing the cells to attach. On the day of the experiment, the medium was removed and incubated in fresh medium ( $1 \% \mathrm{FBS}, 1.3 \mathrm{~mL}$ ) for $1 \mathrm{~h}$ at $37^{\circ} \mathrm{C}$ and $5 \% \mathrm{CO}_{2}$. Radiolabelled conjugates $\left[{ }^{177} \mathrm{Lu}(\mathrm{L})\right](\mathrm{L}=\mathbf{1}-\mathbf{3})(2.5 \mathrm{pmol}$ per well, $2.5 \mathrm{pM}$ solution in PBS) were added and the cells were incubated for different time points $(30,60,120,240 \mathrm{~min})$ in triplicates to allow binding and internalization. Nonspecific receptor binding and internalization was determined by blocking experiments in the presence of a 1000 -fold excess of NT(8-13) as a blocking agent (2.5 nmol per well, $2.5 \mathrm{nM}$ solution in $\mathrm{H}_{2} \mathrm{O}$ ). After each time point, the supernatant was removed and the cells were washed twice with PBS $(1 \mathrm{~mL})$. The combined supernatants represent the free, unbound fraction of radioactivity. Receptor-bound radioactivity was determined by incubating the cells on ice twice for 5 min with an acidic glycine solution $(1 \mathrm{~mL} ; 100 \mathrm{nM} \mathrm{NaCl}$, $50 \mathrm{nM}$ glycine, $\mathrm{pH} 2.8$ ). The internalized fraction was isolated by lysis of the cells with $1 \mathrm{M} \mathrm{NaOH}(1 \mathrm{~mL})$ for $10 \mathrm{~min}$ at $37^{\circ} \mathrm{C}$ and $5 \% \mathrm{CO}_{2}$. The wells of the lysed cells were washed twice with $1 \mathrm{~mL} \mathrm{NaOH}$. The radioactivity of the fractions were measured quantitatively in a gamma counter and calculated as a percentage of applied dose. Data was fitted by non-linear regression with GraphPad Prism $5.0(n=3$ in triplicate).

\section{Binding saturation studies}

HT 29 cells in six-well plates were prepared as described above. In order to reach receptor saturation, the cells were incubated with increasing concentrations of the peptide conjugates $\left[{ }^{177} \mathrm{Lu}(\mathrm{L})\right](\mathrm{L}=\mathbf{1}-\mathbf{3} ; 0.1,0.5,1,5,10,20,50$, $75,100,200 \mathrm{nM})$. Non-specific binding was determined by blocking experiments using excess Neurotensin (8-13) solution $(2.5 \mathrm{nmol} / 1 \mathrm{~mL}$ per well, corresponding to $2.5 \mu \mathrm{M})$. After incubation of $1 \mathrm{~h}$ at $37^{\circ} \mathrm{C}$ and $5 \% \mathrm{CO}_{2}$, the supernatant was removed and the cells were washed twice with PBS ( $1 \mathrm{~mL}$ per well). The combined supernatants represent the free, unbound radiopeptide fraction. In order to determine the receptor bound and internalized fraction, the cells were lysed with $1 \mathrm{M} \mathrm{NaOH}(1 \mathrm{~mL}$ per well) for $10 \mathrm{~min}$ at $37^{\circ} \mathrm{C}$ and washed twice with $1 \mathrm{M} \mathrm{NaOH}(1 \mathrm{~mL}$ per well). The free and the receptor bound fractions were measured in a gamma counter for quantification. Dissociation constants $\left(K_{\mathrm{D}}\right)$ were calculated from the specific binding data by performing a non-linear regression using GraphPad Prism5 $(n=3$ in triplicate). 
Acknowledgment. We thank the Swiss National Science Foundation (project SNF-132280) for financial support and Dr. Andreas Bauman, Christiane A. Kluba and Sandra Vomstein (University of Basel Hospital) for scientific discussions and technical assistance.

\section{References}

1. Schottelius, M., Wester, H. J.: Methods 48, 161 (2009).

2. Reubi, J. C., Maecke, H. J.: J. Nucl. Med. 49, 1735 (2008).

3. Maschauer, S., Einsiedel, J., Hocke, C., Hubner, H., Kuwert, T., Gmeiner, P., Prante, O.: ACS Med. Chem. Lett. 1, 224 (2010).

4. Alshoukr, F., Prignon, A., Brans, L., Jallane, A., Mendes, S, Talbot, J. N., Tourwe, D., Barbet, J., Gruaz-Guyon, A.: Bioconjug. Chem. 22, 1374 (2011).

5. Garcia-Garayoa, E., Allemann-Tannahill,L., Blauenstein, P., Willmann, M., Carrel-Remy, N., Tourwe, D., Iterbeke, K., Conrath, P., Schubiger, P. A.: Nucl. Med. Biol. 28, 75 (2001).

6. Garcia-Garayoa, E., Blauenstein, P., Blanc, A., Maes, V., Tourwe, D., Schubiger, P. A.: Eur. J. Nucl. Med. Mol. Imag. 36, 37 (2009).

7. Zhao, D. Z., Pothoulakis, C.: Peptides 27, 2434 (2006).

8. Geisler, S., Berod, A., Zahm, D. S., Rostene, W.: Peptides 27, 2364 (2006).

9. Boules, M., Fredrickson, P., Richelson, E.: Peptides 27, 2553 (2006).

10. Myers, R. M., Shearman, J. W., Kitching, M. O., RamosMontoya, A., Neal, D. E., Ley, S. V.: ACS Chem. Biol. 4, 503 (2009).
11. Maoret, J. J., Pospai, D., Rouyerfessard, C., Couvineau, A., Laboisse, C., Voisin, T., Laburthe, M.: Biochem. Biophys. Res. Commun. 203, 465 (1994).

12. Reeve, J. G., Goedert, M., Emson, P. C., Bleehen, N. M.: Rec. Res. Cancer Res. 99, 175 (1985).

13. Seethalakshmi, L., Mitra, S. P., Dobner, P. R., Menon, M., Carraway, R. E.: Prostate 31, 183 (1997).

14. Souaze, F., Dupouy, S., Viardot-Foucaut, V., Bruyneel, E., Gespach, C., Gompel, A., Forgez, P.: Cancer Res. 66, 6243 (2006).

15. Alshoukr, F., Rosant, C., Maes, V., Abdelhak, J., Raguin, O., Burg, S., Sarda, 1., Barbet, J., Tourwe, D., Pelaprat, D., GruazGuyon, A.: Bioconjug. Chem. 20, 1602 (2009).

16. Wild, D., Béhé, M., Wicki, A., Storch, D., Waser, B., Gotthardt, M., Keil, B., Chrsitofori, G., Reubi, J. C., Maecke, H. J.: J. Nucl. Med. 47, 2025 (2006).

17. Zhang, H. W., Schuhmacher, J., Waser, B., Wild, D., Eisenhut, M., Reubi, J. C., Meacke, H. R.: Eur. J. Nucl. Med. Mol. Imag. 34, 1198 (2007).

18. Smith, C. J., Gali, H., Sieckman, G. L., Hayes, D. L., Owen, N. K., Mazuru, D. G., Volkert, W. A., Hoffman, T. J.: Nucl. Med. Biol. 30, 101 (2003).

19. Garcia-Garayoa, E., Maes, V., Blauenstein, P., Blanc, A., Hohn, A., Tourwe, D., Schubiger, P. A.: Nucl. Med. Biol. 33, 495 (2006).

20. Schroeder, R. P., Mueller, C., Reneman, S., Melis, M. L., Breeamn, W. A., de Blois, E., Bangma, C. H., Krenning, E. P., van Weerden, W. M., de Jong, M.: Eur. J. Nucl. Med. Mol. Imag. 37, 1386 (2010).

21. Okarvi, S. M.: Cancer Treat. Rev. 34, 13 (2008).

22. Good, S., Walter, M. A., Waser, B., Wang, X. J., Muller-Brand, J., Behe, M. P., Reubi, J. C., Maecke, H. R.: Eur. J. Nucl. Med. Mol. Imag. 35, 1868 (2008). 